よい，同様な理由により「フロント」増感紙の愿さを 堌すとコントラストが減少する傾向にあり更にX 線の 写真作用が重複して被写体の密度に応じ変化する適 当な厚さがある事を明らかにした。

（第 9 回総会発表）

\section{〔42〕後面增感紙のみに依る $\mathbf{X}$ 線写真に就いて} 德島市民病院 大隅 豊 池田茂之

1. 複合増感紙の濃度及び前面, 後面等に依る濃度の 関係

2. 前記に依る鮮鋭度及び鮮明度の関係

3. 以上に依ってフィルムの乳剂片面瑟付のみにても 可なりや，増感紙は前面か後面かのいずれかのみ で可なりや。

4. これに生ずるX線量, 增感紙並にフィルム等の経 費の如何及び疑義等

を検討し後面增感紙のみで鮮鋭度をよくし，てれとは 逆に減少したX線量を補い胸部 $\mathrm{X}$ 線写真撮影を行った 事に就いて報告。

（第 7 回総会発表）（第 7 巻第 1 号揭載）

〔43〕高圧摄影低圧撮影に於ける 使用增感紙の選定について
部国人緗紧国工場病院 石 河 英夫 高圧撮影に於ては増感紙の前葉増感紙, 後葉増感紙 の溃光膜の厚さの比率足減少せしめ，てれが為䲗鋭度

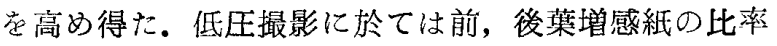
を高くする必要ありてれについて説明報告した。

(第 9 回総会発表)

\section{〔44】格子增感紙とその使用経過に就いて} 柏原町立診療所 野 村 正 美 大阪回生病院 井村他喜夫 池田回生病院 村 西 清

(第 9 回総会発表)

〔45〕小型 X線装置に依る超高感度增感紙の応用

東邦大学医学部 飯塚 芳 郎 青柳 恭司 大日本塗料 大谷傮吉 潼沢達児

特殊螢光体に依る超高感度増感紙の性能を増感度, 鮮鋭度, 残光の 3 方面より検討しその結果本増感紙を 小型X線装置に応用することに依り従来至難とされて おった身体各部位の撮影に極めて好結果を得たので報 告した。

（第10回総会発表）

\title{
IV. 薬品及び現像処理の部
}

（造影剂，現像薬品及び現像喑室処理）

〔1〕近時バリウムの犋と中毒に就て

$$
\text { 岩手医大 中沢 勇 }
$$

小林善吉

消化器の優良なレントグン写真を得るには良質なバリ ウムを用うる事レントゲン線财收度及び沈降度の最適 なるのを使用しなければならない事はいう迄もない が，注意すべき事はバリウムを服用して生ずる中毒症 状である．中毒症状は可溶性バリウムの含有量に左右 される事は論を俟たない。近時市販のバリウム数種の 定量分析並に沈降速度の試駼結果之過去 $2 \cdot 3$ 経験し た中毒症状の飲用量に就て報告.

（第 5 回総会発表）（第 5 巻1·2号掲載）

\section{〔2〕各種造影㘊のXX線吸収に就いて} 名古屋大学医学部

奥村彦太郎 宇佐美加代
竹内 稔

$\mathrm{X}$ 線診断上造影剤は必要欠くべからざるものであり

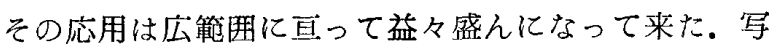
真撮影上江必要なる各種造影剤の $\mathrm{X}$ 線吸収の比較及び 管電圧と吸収度及び潾度と如何なる関係を有するかキ ュストネル測定器により測定した結果を報告。

（第 9 回総会発表）（第 9 巻第 4 号掲載）

\section{〔3〕屍体血管摄影の造影剤について}

日本赤十字社産院 金 沢 章 病理解剖学上，屍体解剖前にXX線的に血管の状態を 明らかにすべき造影剂に就いて，2.3の種類で実験 した写真を供覧し，在来の血管造影剂に対し廉価なる 硫酸バリウムの応用が新処方にてはぼ目的を達し得る 事を報告。

（第 8 回総会発表）（第 8 巻第 1 号掲載） 